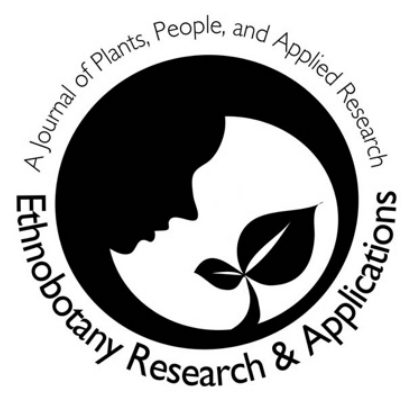

\title{
Ethnobotanical knowledge of Kewrat community of Morang district, eastern Nepal
}

\author{
Bishnu Dev Das, Niroj Paudel, Megharaj Paudel, Madan \\ Kumar Khadka, Sajita Dhakal and Amrit KC
}

\section{Research}

\begin{abstract}
Background: Nepal is very rich in castes, ethnic groups and languages that have their own traditional and ritual practices on health care system. Among them, Kewrat is a multilingual group of people living in eastern Terai region of Nepal and its adjoining part of Bihar and West Bengal of India. Their mother tongues are either Surjapuri, Angika or Bengali. Different studies on ethnobotany have been conducted in Nepal but the study on Kewrat community has not been conducted till the date and this study was conducted among the Surjapuri speaker of Kewrat community.
\end{abstract}

Methods: Ethnobotanical study using Ethnobotanical Participatory Appraisal (EPA) method was conducted at Sanbarish (Sunbarshi) municipalit of Morang district of Nepal. Interviews and group discussions were employed among Surjapuri speaking Kewrat people in Sunbarshi municipality ward number 4 (Kashijan), 5 (Ramanpur), 6 (Saranpur) and 7 (Bardanga) among 65 individuals including elderly people and traditional healers following the transect walk survey.

Results: A total of 60 medicinal plant species belonging to 37 families were reported based on their religious practices and believes from study area. Among them, 29 herbs (48\%), 12 shrubs (20\%), 15 tree $(25 \%)$ and 4 climbers $(7 \%)$ were recorded. Kewrat people are found to be very rich in ethnobotanical knowledge. The plants resources have been used by Kewrat people in treating 35 different types of ailments along with traditional uses in different ritual and religious occasions.

Conclusions: The people of Surjapuri speaker of Kewrat community have a very crucial knowledge of medicinal plants. The study has documented the baseline data for further studies in the field of ethnobotany, medicinal plants and diversity. The ethnobotanical knowledge of Kewrat people is based on strong belief system and custom. They depend mostly on plant resources for curing ailments. This study suggests that the indigenous community of Kewrat has an in-depth knowledge of use of local plant resources.

Keywords: Ailments, Indigenous knowledge, Kewrat community, Medicinal plant, Plant diversity, Surjapuri language, Traditional use.

\section{Correspondence}

Bishnu Dev Das ${ }^{1^{*}}$, Niroj Paudel ${ }^{2}$, Megharaj Paudel $^{3}$, Madan Kumar Khadka ${ }^{4}$, Sajita Dhakal ${ }^{5}$ and Amrit $\mathrm{KC}^{6}$

${ }^{1}$ Department of Botany, Mahendra Morang Aadarsh Multiple Campus Biratnagar (Tribhuvan University), Nepal.

2Department of Applied Plant Science, Kangwon National University, Chuncheon 24341, Republic of Korea.

${ }^{3}$ Division Forest Office, Parbat, Ministry of Industry, Tourism, Forest and Environment, Gandaki Province, Pokhara, Nepal.

${ }^{4}$ Plant Research Centre, Ilam, Department of Plant Resources, Ministry of Forests and Environment, Province One, Nepal.

${ }^{5,6}$ National Herbarium and Plant Laboratories,Department of Plant Resources (DPR), Ministry of Forests and Environment.Godawari, Lalitpur, Nepal.

*Corresponding Author: bishnudevnp@gmail.com

Ethnobotany Research \& Applications 21:01 (2021) 


\section{Background}

Globally, different ethnic groups have been practicing traditional means of health care by using medicinal plants (Sheng-Ji 2001). It was also estimated that about $80 \%$ of Asian and African populations use traditional medicine for their healthcare needs (WHO 2008). Mostly the indigenous people who live in rural areas, the people depend on traditional practices of health care system using medicinal plants since long time ago (Manandhar 1993, Thorsen \& Pouliot 2015).

The term ethnobotany was probably first coined as a term in 1895 by one of the Florida's early botanists, John W. Harshberger. He described ethnobotany as the study of the interaction between people, plants, and culture (Harshberger 1896). It refers to studies that explore the reciprocal relationship among plants, people and traditions (Cotton 1996). The study of ethnobotany, thus, may go far in explaining and predicting patterns and processes of the plant people relationship through the use of ecological theories, methods and analyses applied to questions within ethnoecology and ethnobotany (Albuquerque \& Lucena 2005). Thus ethnobotany is an interdisciplinary science, involving knowledge and use of plants and their ecology in the context of their cultural, social and economic significance. It is the study of interactions between people and plants at spatial, temporal, historical and cross-cultural scales, particularly the role of plants in human culture, how humans have used and modified plants, and how they represent them in their systems of knowledge (Austin 2004).

There are 125 caste/ethnic groups, 123 languages and 10 religious groups in Nepal (CBS 2011). There are many studies related to medicinal plants and associated indigenous knowledge in Nepal have been Nepal carried out (Rai 2004, Luitel et al. 2014, Mallaet al. 2015, Paudel et al. 2017,Bhattarai 2018, Paude let al. 2018a, 2018b).

Various studies have been conducted in the field of applications of plant resources such as Rai (2004) reported 64 plant species used by Meche people from Jhapa district, Luitel et al. (2014) reported a total of 161 plant species belonging to 86 families and 144 genera to cure 89 human ailments used by the Tamang community in the Makawanpur district of central Nepal. Malla et al.(2015) documented a total of 132 ethnomedicinal plant species belonging to 99 genera and 67 families used by ethnic people in Parbat district of western Nepal, Paudel et al. (2017) reported more than 25 species of medicinal plants out of 95 documented plant species from Arghakhnachi district of western Nepal, Bhattarai (2018) explored 30 plants from 24 families and 29 genera used by Thami community from Ilam district of eastern Nepal, Paudel et al. (2018a) reported 12 medicinal plants from Kathmandu valley of central Nepal, and also Paudel et al. (2018b) explored 32 medicinal plants from Biratnagar of eastern Nepal.

Nepal is rich in both socio-cultural and biological diversity due to having its unique geography and climatic variations. There are 125 caste/ethnic groups, 123 languages and 10 religious groups in Nepal (CBS 2011).In recent years, there are many studies related to medicinal plants and associated indigenous knowledge in Nepal have been carried out (Rai 2004, Luitel et al. 2014, Malla et al. 2015, Paudel et al. 2017,Bhattarai 2018, Paudel et al. 2018a, 2018b) but there is no any ethnobotanical documentation has occurred in Kewrat group till the date. Therefore, this study has been designed to document the ethnobotanical knowledge of Kewrat community of Surjapuri language speaker and also to explore the plant diversity of the study area.

\section{Materials and Methods \\ Study area}

There are varieties of plant species and different part used by Kewrat community in healing the different ailments. The traditional healers believed that medicinal plants should be collected only during specific day and time silently during the collection. During the collection, we should pray for the specific goddess with Mantra to activate the plant for particular function, otherwise the plant won't work as medicine. It is believed and found in practice that after recovery, patient should sacrifice goat, duck or pigeon or offer banana and milk according to the requirements of specific goddess. Thus, it can be concluded that the ethnobotanical knowledge of Kewrat people is based on strong belief system and custom.

Morang district is situated in the south-east part of the Koshi zone and is geographically located between the latitudes $26^{\circ} 20^{\prime} \mathrm{N}$ to $26^{\circ} 53^{\prime} \mathrm{N}$ and longitudes $87^{\circ} 16^{\prime} \mathrm{E}$ to $87^{\circ} 41^{\prime} \mathrm{E}$.It has a total area of $1,855 \mathrm{~km}^{2}$ which is $1.26 \%$ of the total land area of Nepal. The lowest elevation point of the district is 60 meters and the highest is 2410 meters above sea level. The maximum temperature of the district is $42^{\circ} \mathrm{C}$ and the minimum temperature is $3^{\circ} \mathrm{C}$ and receives $1,812.8 \mathrm{~mm}$ rainfall annually. Morang has one metropolitan city (Biratnagar), eight municipalities and eight rural municipalities. The total area of Morang is $1,855 \mathrm{~km}^{2}$.

The study was conducted in Sanbarish (Sunbarshi) municipality ward no 4 (Kashijan) and 5 (Ramanpur), 6 (Saranpur) and 7 (Bardanga) of Morang district were selected due to the presence of high Kewrat populated area (Fig. 1). The municipality is divided 
into 9 wards and total area is $106.4 \mathrm{~km}^{2}$ and the population of the municipality is 50758 , according to the census of Nepal in 2011. The Sunabarshi Municipality name was given from oldest Sunabarshi Maharajthan (divine king of the area). The study area is located between $26.45^{\circ} \mathrm{N}$ to $87.54^{\circ} \mathrm{E}$. Climatically the study area is tropical and a part of Terai region. The total number of Kewrat population is about 15,000 in study area.
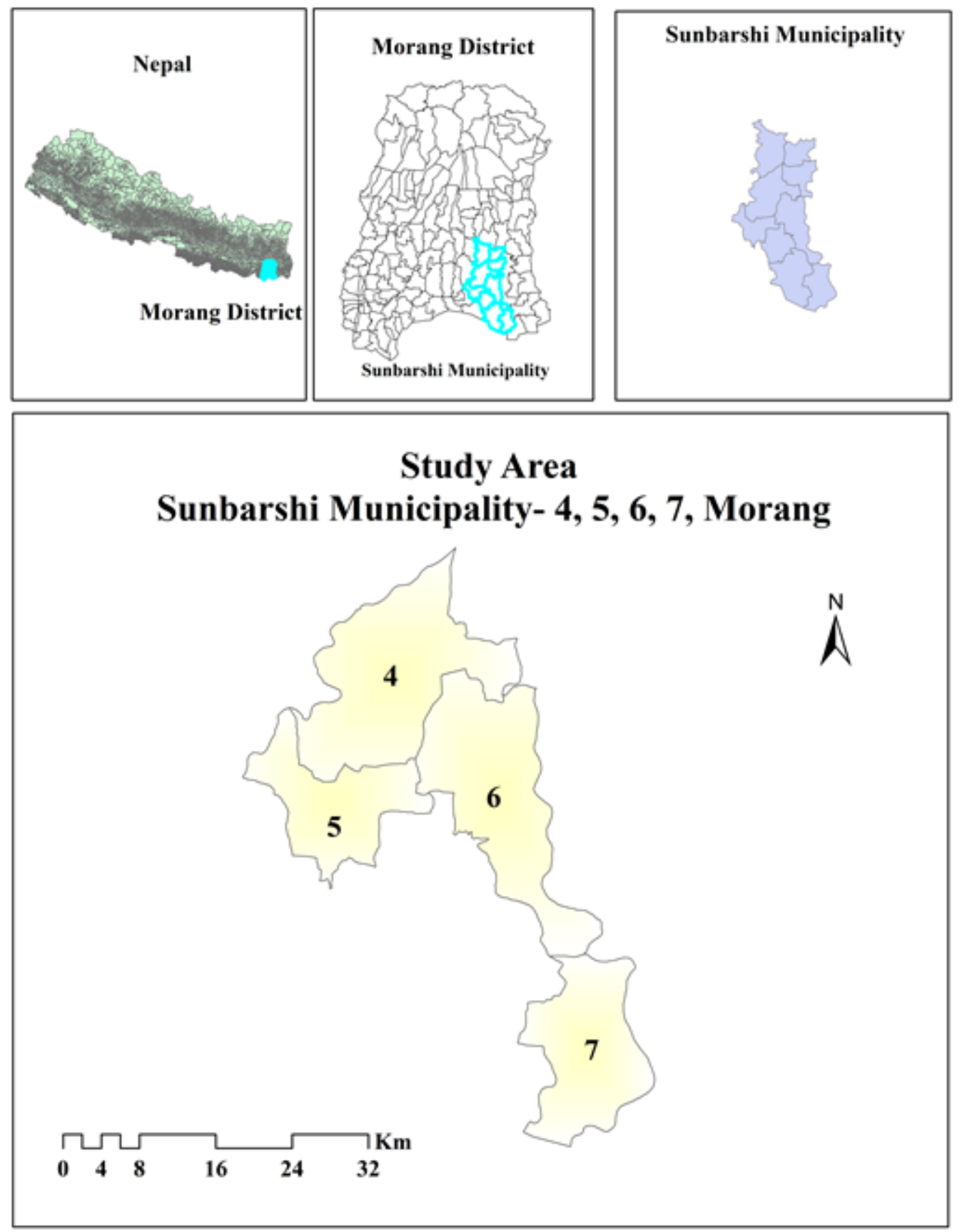

Figure1. Map of study area

\section{Field Methods and data collection}

During the period of January 2019 to March 2020, field work investigation was carried out to formulate the ethnobotanical information and their medicinal verification in the study area. Participatory Rural Appraisal (PRA) technique (Bazai et al. 2013) was applied to get information from the local people about the knowledge of different uses of plant species, location, and place of availability and category of uses. The Interviews were taken with 40 men and 25 women from different villages that have a strong linkage and experience with folk medicine practices. This interview technique employed questionnaire 
about the use of plant for different purposes like medicine, food, fodder, timber, firewood etc. Similarly, old aged and professional health healers (locally called Dhami or Ojha) of Kewrat community were gathered and asked for use of plants for different purposes like medical, social, and cultural uses and other used such food, fodder, fuel, fiber, timber etc. Survey was carried out along the home gardens, roadsides and agriculture fields with the help of key informants. The plant specimens were collected by the help of local people. During the collection, field notes on taxonomic characters such as location, habit, habitat, color of flower and period of flowering and fruiting were noted for identification. The collected specimens were properly tagged with field number before keeping them in polythene bags.

The collected specimens were used for the preparation of herbarium specimens by pressing in between newspapers and dried by using standard technique (Jain \& Rao 1967) and identified using literature (Polunin \& Stainton 1984, Press et al. 2000, Manandhar 2002). Local names of the medicinal plants were noted in the field. Voucher specimens were deposited at the Department of Botany, Mahendra Morang Aadarsh Multiple Campus Biratnagar (Tribhuvan University), Nepal.

\section{Results and Discussions}

A total of 60 different plant species belonging to 37 families were reported (Table 1) based on their religious practices and believes from study area comprising 22 wild species and 38 cultivated. Among them, 29 herbs (48\%), 12 shrubs (20\%), 15 tree (25\%) and 4 climbers (7\%) were recorded (Fig. 2). The leaves and stem of Juniperus indica Bertol were bought from market or collected from hill sides and commonly stored for medicinal as well as spiritual uses in different ritual ceremonies specially for its pleasant aroma. The plants resources have been used by Kewrat people in different 35 types of ailments such as fever, pneumonia, toothache, fever, burn, diabetic, indigestion, skin diseases, jaundice, cough, cold, anxiety, sleeplessness, eczema, dysentery, diarrhea, vitiligo, arthritis, common colds, tonsillitis, high blood pressure, mental disorders, meditation, piles, abdominal pain, leprosy, lice, nausea, ,vomiting, gastric, wounds and cuts, appetizer, eye swelling, rheumatism and constipation along with traditional uses in different ritual and religious occasions (Table 1). The overall results showed that the people of Kewrat community have very rich in ethnobotanical knowledge.

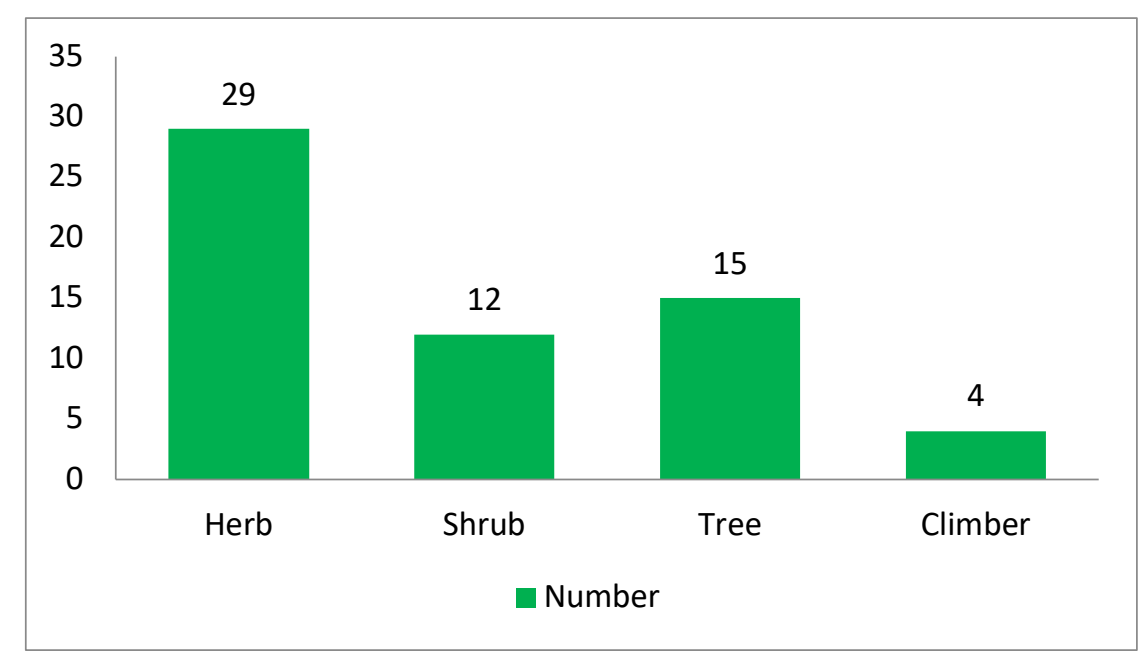

Figure 2. Habit of studied plants

Application of medicinal plant species in the treatment of in various 35 ailments in different forms shows that people of the Kewrat community have indigenous knowledge in the field of treatment. The most commonly used plant species is Acorus calamus $L$ in the treatment of cough, cold and sore throat. Similarly, Azadirachta indica and Aloe vera (L.) Burm. f. were also found to be used frequently throughout the study. The application of a small branch of Ziziphus xylopyrus (Retz.) Wild in the main gate of house is supposed to be protecting the newly borne baby and mother from devil eyes.
Out of medicinal applications, some other interesting applications are also investigated during the study. The fresh shoots and corms of Colocasia esculenta (L.) Schott are cooked as vegetables and leaves are used to prepare a special traditional dish called 'Darkach'. The tree of Ficus religiosa L. is of great religious value and is worshipped with water on Saturday morning. Straw of Oryza sativa $L$ is good sources of fodder and flour prepared from rice grains is used to prepare cultural dishes such as pittha/bagiya, Bhakka and roti (bread) etc. 
Table1. List of documented plant species with their various application ( $N=$ Nepali name, $S=$ Surjapuri name, $V=$ Voucher number)

\begin{tabular}{|c|c|c|c|c|c|c|}
\hline Scientific name & Family & Local name (S) & Habit & Part Used & Ailments & Mode of application \\
\hline $\begin{array}{l}\text { Abelmoschus esculentus } \mathrm{L} \text {. } \\
(\mathrm{V}=11)\end{array}$ & Malvaceae & $\begin{array}{l}\text { Ramtoriya(N); } \\
\text { Ramtarai(S) }\end{array}$ & Herb & Fruits, stem & $\begin{array}{l}\text { Urinary problems, } \\
\text { constipation }\end{array}$ & $\begin{array}{l}\text { Fruits are eaten as vegetables (curry) to } \\
\text { cure urinary problems and constipation. }\end{array}$ \\
\hline $\begin{array}{l}\text { Achyranthes aspera } \mathrm{L} . \\
(\mathrm{V}=18)\end{array}$ & Amaranthaceae & Datiwan (N); Chichiri (S) & Herb & Root, stem & $\begin{array}{l}\text { Fever, Pneumonia } \\
\text { toothache }\end{array}$ & $\begin{array}{l}\text { A decoction of plant is applied Stem is } \\
\text { used as toothbrush. }\end{array}$ \\
\hline $\begin{array}{l}\text { Acorus calamus } \mathrm{L} . \\
(\mathrm{V}=1)\end{array}$ & Acoraceae & Bojo (N), Banchwa (S) & Herb & Rhizome & $\begin{array}{l}\text { Cough, cold, sore } \\
\text { throat }\end{array}$ & $\begin{array}{l}\text { Small piece of dried rhizome is chewed } \\
\text { thrice a day until recovery. }\end{array}$ \\
\hline $\begin{array}{l}\text { Allium sativum } \mathrm{L} . \\
(\mathrm{V}=26)\end{array}$ & Amaryllidaceae & Lasun(N); Rosun (S) & Herb & Leaves, bulb & $\begin{array}{l}\text { Fever, and cough, } \\
\text { high }\end{array}$ & $\begin{array}{l}\text { Raw bulb or paste (3-5 )is used have } \\
\text { once a day for a week. }\end{array}$ \\
\hline $\begin{array}{l}\text { Aloe vera(L.) Burm.f. } \\
(\mathrm{V}=41)\end{array}$ & Asphodelaceae & Ghiyu kumari (N; S) & Herb & Leaf & $\begin{array}{l}\text { Pimples, high blood } \\
\text { pressure, constipation }\end{array}$ & $\begin{array}{l}\text { Leaf pulp is applied to cure pimples } \\
\text { twice a day for a week. Pulp juice is } \\
\text { used to drink twice a day for a week to } \\
\text { cure constipation and high blood } \\
\text { pressure }\end{array}$ \\
\hline $\begin{array}{l}\text { Annona squamosa } L . \\
(V=43)\end{array}$ & Annonaceae & Sarifa(N); Sarfa(S) & Tree & Ripen fruit & Indigestion & $\begin{array}{l}\text { Ripen fruits are eaten to cure } \\
\text { indigestion. }\end{array}$ \\
\hline $\begin{array}{l}\text { Artocarpus heterophyllus } \\
\text { Lam. } \\
(\mathrm{V}=25)\end{array}$ & Moraceae & $\begin{array}{l}\text { Rukhkatahar } \\
\text { (N);Dahuwa(S) }\end{array}$ & Tree & Leaf, fruit & $\begin{array}{l}\text { Skin diseases and } \\
\text { dysentery }\end{array}$ & $\begin{array}{l}\text { Leaf paste is used for skin diseases. } \\
\text { Fresh ripen fruits or a decoction of is } \\
\text { used to treat dysentery }\end{array}$ \\
\hline $\begin{array}{l}\text { Azadirachta indica A.Juss } \\
(\mathrm{V}=28)\end{array}$ & Meliaceae & Neem(N;S) & Tree & Leaf, stem & $\begin{array}{l}\text { Skin } \\
\text { diseases,toothache }\end{array}$ & $\begin{array}{l}\text { Leaves are boiled in water for } 10 \\
\text { minutes and get a th after cooling. Stem } \\
\text { is used as toothbrush. }\end{array}$ \\
\hline $\begin{array}{l}\text { Cajanus cajan (L.) Huth } \\
(\mathrm{V}=27)\end{array}$ & Fabaceae & Rahar (N); Lahir(S) & Shrub & Leaf, & $\begin{array}{l}\text { Jaundice, cough and } \\
\text { cold and diarrhea }\end{array}$ & $\begin{array}{l}\text { Leaf juices and seeds are cooked as } \\
\text { soup called as 'daal to cure. }\end{array}$ \\
\hline $\begin{array}{l}\text { Cannabis sativa } \mathrm{L} \text {. } \\
(\mathrm{V}=44)\end{array}$ & Cannabaceae & Bhang (N; S) & Herb & Leaf & $\begin{array}{l}\text { Anxiety, } \\
\text { sleeplessness }\end{array}$ & $\begin{array}{l}\text { Juice extracted from 3-5 leavesis used } \\
\text { to have once a day for } 2 \text { weeks. }\end{array}$ \\
\hline $\begin{array}{l}\text { Carica papayaL. } \\
(\mathrm{V}=2)\end{array}$ & Caricaceae & Meba (N); Popita(S) & Shrub & Leaf, fruits & Eczema & Leaf latex is used to treat eczema \\
\hline $\begin{array}{l}\text { Citrus aurantifolia (Christ.) } \\
\text { Swingle } \\
(\mathrm{V}=17)\end{array}$ & Rutaceae & $\begin{array}{l}\text { Kagati (N); Kajjinemu } \\
(\mathrm{S})\end{array}$ & Shrub & Fruits & Indigestion, vitiligo & $\begin{array}{l}\text { Fruit juice with hot water is used to take } \\
\text { twice a day. Fruit juice with Sodium thio- } \\
\text { sulphate }\left(\mathrm{Na}_{2} \mathrm{~S}_{2} \mathrm{O}_{3}\right) \text { is applied on } \\
\text { infected part once a day exposing in } \\
\text { sunlight for half an hour for } 15 \text { days to } \\
\text { cure white spots on skin (vitiligo) }\end{array}$ \\
\hline
\end{tabular}




\begin{tabular}{|c|c|c|c|c|c|c|}
\hline $\begin{array}{l}\text { Clerodendrum viscosum Vent } \\
(\mathrm{V}=45)\end{array}$ & Lamiaceae & Bhant (N/S) & Herb & Leaves, root & Skin disease & $\begin{array}{l}\text { Root and leaf paste is used to cure skin } \\
\text { disease. Stem is used as toothbrush. }\end{array}$ \\
\hline $\begin{array}{l}\text { Colocasia esculanta }(\mathrm{L} .) \\
\text { Schott } \\
(\mathrm{V}=40)\end{array}$ & Araceae & $\begin{array}{l}\text { Pindalu (N); Kachu } \\
\text { aalu(S) }\end{array}$ & Herb & $\begin{array}{l}\text { Leaf, petiole, } \\
\text { corm }\end{array}$ & Cuts and wounds & $\begin{array}{l}\text { The watery substance from petiole is } \\
\text { applied to cure cuts and wounds. }\end{array}$ \\
\hline $\begin{array}{l}\text { Cucurbita maxima Duch. Ex } \\
\text { Poiret } \\
(\mathrm{V}=3)\end{array}$ & Cucurbitaceae & Pharsi(N), Kadma(S) & Climber & Leaf, fruits & Indigestion & $\begin{array}{l}\text { Roasted ripen seeds are eaten to cure } \\
\text { indigestion. Raw leaves and fruits are } \\
\text { eaten as vegetables. }\end{array}$ \\
\hline $\begin{array}{l}\text { Curcuma longa } \mathrm{L} \text {. } \\
(\mathrm{V}=29)\end{array}$ & Zingiberaceae & Besar (N); Haldi(S) & Herb & Rhizome & $\begin{array}{l}\text { Arthritis, cough, } \\
\text { common colds and } \\
\text { tonsillitis. }\end{array}$ & $\begin{array}{l}\text { A decoction of rhizomes powder with } \\
\text { hot milk is used twice a day to cure. }\end{array}$ \\
\hline $\begin{array}{l}\text { Cynodon dactylon (L.) Pers. } \\
(\mathrm{V}=52)\end{array}$ & Poaceae & Dubo (N); Dubri (S) & Herb & Stem, leaf & Cold and cough & $\begin{array}{l}\text { A decoction of stem is used to cure cold } \\
\text { and cough. }\end{array}$ \\
\hline $\begin{array}{l}\text { Datura metel L. } \\
(\mathrm{V}=10)\end{array}$ & Solanaceae & Daturo (N); Dhutra (S) & Shrub & Leaf, fruit & Cough and cold, & $\begin{array}{l}\text { A therapy is given applying ghee } \\
\text { (clarified cow butter or mustard oil) over } \\
\text { the chest of child through leaf applying } \\
\text { mild heat. }\end{array}$ \\
\hline $\begin{array}{l}\text { Dendrocalamus strictus } \\
\text { (Roxb.) Nees } \\
(\mathrm{V}=39)\end{array}$ & Poaceae & $\begin{array}{l}\text { Choyabans (N); Bans } \\
\text { (S) }\end{array}$ & Herb & Stem & Cuts and wounds & $\begin{array}{l}\text { Powder of epidermal green layer of } \\
\text { stem is applied to cure cut and wounds }\end{array}$ \\
\hline $\begin{array}{l}\text { Elaeocarpus sphaericus } \\
\text { (Gaertn.) K. Schum. } \\
(\mathrm{V}=30)\end{array}$ & Elaeocarpaceae & $\begin{array}{l}\text { Rudraksha(N); } \\
\text { Rudraksha(S) }\end{array}$ & Tree & Fruit & $\begin{array}{l}\text { High blood pressure, } \\
\text { mental disorders, } \\
\text { meditation }\end{array}$ & $\begin{array}{l}\text { Fruits juice is useful to cure high blood } \\
\text { pressure and mental disorders. }\end{array}$ \\
\hline $\begin{array}{l}\text { Eulaliopsis binata (Retzius) } \\
\text { C.E.Hubbard } \\
(\mathrm{V}=4)\end{array}$ & Poaceae & Babiyo(N); Iluwa(S) & Herb & Leaf & Indigestion & $\begin{array}{l}\text { Plant leaves are used to feed to cattle to } \\
\text { cure indigestion. }\end{array}$ \\
\hline $\begin{array}{l}\text { Ficus benghalensis } \mathrm{L} . \\
(\mathrm{V}=31)\end{array}$ & Moraceae & $\operatorname{Bar}(\mathrm{N} / \mathrm{S})$ & Tree & Stem & $\begin{array}{l}\text { Dysentery, diarrhea } \\
\text { and diabetes, } \\
\text { toothache. }\end{array}$ & $\begin{array}{l}\text { Bark decoction is used to cure } \\
\text { dysentery, diarrhea and diabetes. Latex } \\
\text { is applied to cure pains, rheumatism } \\
\text { and toothache. }\end{array}$ \\
\hline $\begin{array}{l}\text { Ficus glaberima Blume } \\
(\mathrm{V}=32)\end{array}$ & Moraceae & Pakhuri (N); Pakhar (S) & Tree & Fruit, stem & Jaundice & $\begin{array}{l}\text { The past of tree bark with the bark of } \\
\text { Mango is applied on the skin the } \\
\text { presence of sunlight to cure jaundice }\end{array}$ \\
\hline $\begin{array}{l}\text { Ficus religiosa } \mathrm{L} . \\
(\mathrm{V}=46)\end{array}$ & Moraceae & Peepal (N/S) & Tree & Leaf, stem & Jaundice & $\begin{array}{l}\text { The past of tree bark with the bark of } \\
\text { Mango is applied on the skin the } \\
\text { presence of sunlight to cure jaundice }\end{array}$ \\
\hline
\end{tabular}




\begin{tabular}{|c|c|c|c|c|c|c|}
\hline $\begin{array}{l}\text { Juniperus indica Bertol } \\
(\mathrm{V}=48)\end{array}$ & Cupressaceae & Dhupee (N);Dhuman(S) & Tree & Leaf & $\begin{array}{l}\text { Diarrhea, piles, } \\
\text { abdominal pain, }\end{array}$ & $\begin{array}{l}\text { Leaf juice is used to cure twice a day for } \\
15 \text { days. }\end{array}$ \\
\hline $\begin{array}{l}\text { Lablab purpureus (L.) Sweet. } \\
(\mathrm{V}=51)\end{array}$ & Fabaceae & $\begin{array}{l}\text { Hiundesimi (N); Puthiya } \\
\text { (S) }\end{array}$ & Climber & Leaf & Skin diseases & $\begin{array}{l}\text { Leaf juice is applied to cure skin } \\
\text { diseases. The plant is used as fodder. }\end{array}$ \\
\hline $\begin{array}{l}\text { Lagenaria siceraria (Molina) } \\
\text { Standley } \\
(\mathrm{V}=5)\end{array}$ & Cucurbitaceae & Lauka (N); Kaddu (S) & Climber & Fruits & Indigestion & Fruits juice is used to cure indigestion. \\
\hline $\begin{array}{l}\text { Lawsonia inermis } L . \\
(\mathrm{V}=6)\end{array}$ & Lythraceae & Mehandi (N/S) & Shrub & Leaf & Skin diseases & $\begin{array}{l}\text { Leaf paste is applied to cure skin } \\
\text { diseases. Leaf paste with khair } \\
\text { (Senegalia catechu) }\end{array}$ \\
\hline $\begin{array}{l}\text { Leucas aspera (Willd.) Link } \\
(\mathrm{V}=47)\end{array}$ & Lamiaceae & Dunphi (S) & Herb & Leaf, flowers & Fever, rheumatism & $\begin{array}{l}\text { Decoction of leaves is used for } \\
\text { treatment. }\end{array}$ \\
\hline $\begin{array}{l}\text { Madhuca longifolia (Koeing) } \\
\text { Machr. } \\
(\mathrm{V}=33)\end{array}$ & Sapotaceae & Mahuwa(N; S) & Tree & Stem, & $\begin{array}{l}\text { Diabetes, cough and } \\
\text { cold }\end{array}$ & $\begin{array}{l}\text { Decoction of the bark is given to cure } \\
\text { diabetes. A decoction of flower is about } \\
4 \text { teaspoonfuls thrice a day is given to } \\
\text { cure cough and cold. }\end{array}$ \\
\hline $\begin{array}{l}\text { Mangifera indica } \mathrm{L} \text {. } \\
(\mathrm{V}=9)\end{array}$ & Anacardiaceae & Aanp(N); Aanm(S) & Tree & Bark & Jaundice & $\begin{array}{l}\text { Paste prepared is applied on skin of } \\
\text { hole body in sunlight }\end{array}$ \\
\hline $\begin{array}{l}\text { Melia azedarach } \mathrm{L} . \\
(\mathrm{V}=7)\end{array}$ & Melaceae & Bakaino (N); Bakaina(S) & Tree & Leaf & $\begin{array}{l}\text { Leprosy, skin } \\
\text { diseases, lice }\end{array}$ & $\begin{array}{l}\text { Bark juice is used to cure leprosy and } \\
\text { skin diseases. Decoction made from } \\
\text { fruits and flowers is used to kill lice. } \\
\text { Leaves are used as fodder. }\end{array}$ \\
\hline $\begin{array}{l}\text { Mentha spicata } L . \\
(\mathrm{V}=49)\end{array}$ & Lamiaceae & Pudina (N; S) & Shrub & Leaf, & $\begin{array}{l}\text { Nausea, diarrhea, } \\
\text { dysentery, vomiting } \\
\text { and gastric }\end{array}$ & $\begin{array}{l}\text { Leaf juice is given twice a day for a } \\
\text { week for better result. Leaves are also } \\
\text { used to prepare pickle. }\end{array}$ \\
\hline $\begin{array}{l}\text { Momordica charantia } \mathrm{L} . \\
(\mathrm{V}=34)\end{array}$ & Cucurbitaceae & Karela (N); Karla (S) & Climber & Leaf, fruits & $\begin{array}{l}\text { Eczema., high blood } \\
\text { pressure }\end{array}$ & $\begin{array}{l}\text { The leaf juice is used to cure skin } \\
\text { diseases like eczema. The fruits are } \\
\text { used to cure high blood pressure. }\end{array}$ \\
\hline $\begin{array}{l}\text { Moringa oleifera Lam. } \\
(\mathrm{V}=50)\end{array}$ & Moringaceae & Sajiun (N/S) & Shrub & Fruits & Indigestion & $\begin{array}{l}\text { The soup prepared from leaves or fruits } \\
\text { is applied to cure indigestion. }\end{array}$ \\
\hline $\begin{array}{l}\text { Morus macroura Miq. } \\
(\mathrm{V}=15)\end{array}$ & Moraceae & Kimbu (N); Toot (S) & Shrub & Stem, fruits & Wounds and cuts, & $\begin{array}{l}\text { Bark juice is applied to cure cuts and } \\
\text { wounds. Fruits eaten to cure fever and } \\
\text { sore throat. }\end{array}$ \\
\hline $\begin{array}{l}\text { Musa acuminata Colla } \\
(V=35)\end{array}$ & Musaceae & $\begin{array}{l}\text { Kera (N); Malbhog Kela } \\
(\mathrm{S})\end{array}$ & Herb & Leaves, fruit & Indigestion & $\begin{array}{l}\text { Ripen fruits are applied applied to cure } \\
\text { indigestion. }\end{array}$ \\
\hline $\begin{array}{l}\text { Musa balbisiana Colla } \\
(\mathrm{V}=53)\end{array}$ & Musaceae & $\begin{array}{l}\text { Kera (N); Athiya Kela } \\
(\mathrm{S})\end{array}$ & Herb & Root, Fruits & Stomach disorder & $\begin{array}{l}\text { Ripen fruits are eaten to cure stomachic } \\
\text { disorder }\end{array}$ \\
\hline
\end{tabular}




\begin{tabular}{|c|c|c|c|c|c|c|}
\hline $\begin{array}{l}\text { Nelumbo nucifera Gaertn. } \\
(\mathrm{V}=8)\end{array}$ & Nelumbonaceae & $\begin{array}{l}\text { Kamal (N); Chakha Hela } \\
(\mathrm{S})\end{array}$ & Herb & $\begin{array}{l}\text { Tubers, } \\
\text { rhizome, leaf }\end{array}$ & Indigestion & $\begin{array}{l}\text { Tubers and rhizomes are boiled and } \\
\text { eaten as food to cure indigestion. }\end{array}$ \\
\hline $\begin{array}{l}\text { Nyctanthes arbor-tristis } \mathrm{L} . \\
(\mathrm{V}=55)\end{array}$ & Oleaceae & Parijat $(\mathrm{N} ; \mathrm{S})$ & Shrub & Leaf & $\begin{array}{l}\text { Diabetic, high blood } \\
\text { pressure }\end{array}$ & $\begin{array}{l}\text { Decoction of is used once a day to cure } \\
\text { diabetic and high blood pressure }\end{array}$ \\
\hline $\begin{array}{l}\text { Nymphaea nouchali Burm. } \mathrm{f} . \\
(\mathrm{V}=16)\end{array}$ & Nymphaeaceae & Kamal (N); Hela (S) & Herb & $\begin{array}{l}\text { Tubers, } \\
\text { rhizome }\end{array}$ & Indigestion & $\begin{array}{l}\text { Tubers and rhizomes are boiled and } \\
\text { eat as food to cure indigestion }\end{array}$ \\
\hline $\begin{array}{l}\text { Ocimum tenuiflorum } \mathrm{L} . \\
(\mathrm{V}=19)\end{array}$ & Lamiaceae & Tulsi (N; S) & Herb & Leaf & $\begin{array}{l}\text { Common cold, } \\
\text { indigestion }\end{array}$ & $\begin{array}{l}\text { A decoction of leaf is with ginger is } \\
\text { given thrice a day }\end{array}$ \\
\hline $\begin{array}{l}\text { Oryza sativa } \mathrm{L} . \\
(\mathrm{V}=54)\end{array}$ & Poaceae & Dhan (N; S) & Herb & Leaf, fruits & Indigestion, dysentery & $\begin{array}{l}\text { Steamed and boiled rice grains are } \\
\text { given to cure indigestion and dysentery. }\end{array}$ \\
\hline Oxalis comiculata L. $(\mathrm{V}=59)$ & Oxalidaceae & $\begin{array}{l}\text { Chari amilo (N); Amliya } \\
\text { khatta (S) }\end{array}$ & Herb & Leaf & Indigestion & $\begin{array}{l}\text { Leaf decoction is applied to cure } \\
\text { indigestion. }\end{array}$ \\
\hline $\begin{array}{l}\text { Phoenix sylvestris } \mathrm{L} \\
(\mathrm{V}=14) .\end{array}$ & Arecaceae & Khajur (N; S) & Shrub & Juice & Indigestion, appetizer & $\begin{array}{l}\text { The juice technically extracted from the } \\
\text { stem of the plant called 'Tari' is very } \\
\text { nutritious drink and used to cure the } \\
\text { stomachic disorder. }\end{array}$ \\
\hline $\begin{array}{l}\text { Psidium guajava } \mathrm{L} . \\
(\mathrm{V}=24)\end{array}$ & Myrtaceae & 'Bilati’ (N). & Shrub & Leaf, fruits & Dysentery, toothache & $\begin{array}{l}\text { Leaf juice is used to cure dysentery. } \\
\text { Leaf paste is applied for rheumatism, } \\
\text { cuts and wounds. Leaf buds are chewed } \\
\text { to cure toothache. }\end{array}$ \\
\hline $\begin{array}{l}\text { Saccharum officinarum } \mathrm{L} \\
(\mathrm{V}=36)\end{array}$ & Poaceae & Ukhu (N); Kusiyar (S) & Herb & Stem juice & Indigestion, jaundice & $\begin{array}{l}\text { Stem juice is used to treat indigestion } \\
\text { and jaundice. }\end{array}$ \\
\hline $\begin{array}{l}\text { Solanum melongena } \mathrm{L} \\
(\mathrm{V}=23)\end{array}$ & Solanaceae & Bhanta(N); Began (S) & Herb & Fruits & $\begin{array}{l}\text { Cough and cold, skin } \\
\text { diseases }\end{array}$ & $\begin{array}{l}\text { A green fruit is roasted and eaten to } \\
\text { relieve cough and cold. Fruits are used } \\
\text { to offer to Hindu lord 'Shiva' with praying } \\
\text { to cure skin diseases. }\end{array}$ \\
\hline $\begin{array}{l}\text { Swertia angustifolia Buch.- } \\
\text { Ham.ex D.Don. } \\
(\mathrm{V}=37)\end{array}$ & Gentianaceae & Chiraito' (N); Chirato (S) & Herb & Root, leaf & $\begin{array}{l}\text { High blood pressure, } \\
\text { indigestion, }\end{array}$ & $\begin{array}{l}\text { Decoction of whole plants is used to } \\
\text { cure high blood pressure, cough and } \\
\text { cold. }\end{array}$ \\
\hline $\begin{array}{l}\text { Syzygium cumini }(L) \text { Skeels } \\
(\mathrm{V}=20)\end{array}$ & Myrtaceae & Jamun $(\mathrm{N} ; \mathrm{S})$ & Tree & $\begin{array}{l}\text { Leaf, fruits, } \\
\text { stem }\end{array}$ & Dysentery, diabetes. & $\begin{array}{l}\text { Decoction of bark or leaf }(20 \mathrm{ml}) \text { is } \\
\text { drunk twice a day for five days to cure } \\
\text { dysentery. Fruits are eaten to cure } \\
\text { diabetes. }\end{array}$ \\
\hline $\begin{array}{l}\text { Tagetes erecta } \mathrm{L} . \\
(\mathrm{V}=60)\end{array}$ & Asteraceae & Sayapatri (N); Gena (S) & Herb & Leaf, flowers & Pneumonia, & $\begin{array}{l}\text { Leaf juice (half cup) is used twice a day } \\
\text { for five days to cure pneumonia. }\end{array}$ \\
\hline $\begin{array}{l}\text { Tamarindus indica } \mathrm{L} \\
(\mathrm{V}=13)\end{array}$ & Fabaceae & Titri(N); Tetul (S) & Tree & Fruits, & $\begin{array}{l}\text { Indigestion, } \\
\text { stomachache }\end{array}$ & $\begin{array}{l}\text { Paste of three seeds is eaten to cure } \\
\text { stomachache. }\end{array}$ \\
\hline
\end{tabular}




\begin{tabular}{|l|l|l|l|l|l|l|}
\hline $\begin{array}{l}\text { Terminalia bellirica (Gaertn.) } \\
\text { Roxb. } \\
\text { (V=58) }\end{array}$ & Combretaceae & Barro (N) & Tree & Fruits & Constipation gastric & $\begin{array}{l}\text { Four fruits are powdered and it is drunk } \\
\text { with cold water to get relief from } \\
\text { constipation and gastric }\end{array}$ \\
\hline $\begin{array}{l}\text { Terminalia chebula Retz. } \\
\text { (V=22) }\end{array}$ & Combretaceae & Harro (N); Hartikka (S) & Tree & Fruits & Constipation, gastric & $\begin{array}{l}\text { Decoction of fruits is drunk everyday for } \\
\text { gastric and indigestion till recovery. }\end{array}$ \\
\hline $\begin{array}{l}\text { Triticum aestivum L. } \\
\text { V=56) }\end{array}$ & Poaceae & Gahun (N); Gaham(S) & Herb & Grains, & $\begin{array}{l}\text { Indigestion, diabetes, } \\
\text { fever, cold and cough }\end{array}$ & $\begin{array}{l}\text { The bread prepared from wheat flour is } \\
\text { used to eat as food articles to cure } \\
\text { indigestion, diabetes, fever, cold and } \\
\text { cough. }\end{array}$ \\
\hline $\begin{array}{l}\text { Typha angustifolia L. } \\
\text { (V=42) }\end{array}$ & Typhaceae & Pater (N; S) & Herb & Leaf & Jaundice & $\begin{array}{l}\text { Root decoction is applied to cure } \\
\text { jaundice. }\end{array}$ \\
\hline $\begin{array}{l}\text { Urena lobata L. } \\
\text { (V=38) }\end{array}$ & Malvaceae & Bhere jhar (N) & Herb & Leaf, & $\begin{array}{l}\text { Skin infection and } \\
\text { eczema }\end{array}$ & $\begin{array}{l}\text { Young leaves with aerial part of } \\
\text { Drymaria cordata are pasted and } \\
\text { applied for skin infection and eczema }\end{array}$ \\
\hline $\begin{array}{l}\text { Vigna mungo (L.) Hepper. } \\
\text { (V=57) }\end{array}$ & Fabaceae & Mas (N); Maskalai(S) & Herb & Fruits & Indigestion, dysentery & $\begin{array}{l}\text { The soup prepared from seeds is } \\
\text { applied to cure indigestion and } \\
\text { dysentery. }\end{array}$ \\
\hline $\begin{array}{l}\text { Ziziphus xylopyrus (Retz.) } \\
\text { Wild } \\
\text { (V=12) }\end{array}$ & Rhamnaceae & Bayar (N); Bayeer (S) & Shrub & Leaves & Eye Swelling & $\begin{array}{l}\text { Three fresh leaves are touched over the } \\
\text { surface of swollen eye twice a day for 3 } \\
\text { days to cure eye swelling. }\end{array}$ \\
\hline $\begin{array}{l}\text { Zea mays L. } \\
\text { (V=21) }\end{array}$ & Poaceae & Makai (N); Makhai (S) & Herb & Fruits, leaf & Jaundice, indigestion & $\begin{array}{l}\text { The bread prepared from maize grains } \\
\text { is used as food during jaundice and } \\
\text { indigestion }\end{array}$ \\
\hline
\end{tabular}


The traditional practices have become a minor source of income for traditional healers. This practice does not provide sufficient source of income and the new generation don't show any interest in this practice. Similarly, only the jobless and old aged few people having age above 40 were found to be involved in traditional practices and utilization of medicinal plants for social prestige and respect. Thus, there is need for commercialization of such an ethnobotanical knowledge for its preservation and elaboration otherwise this knowledge will be extinct from the society after few decades. Further, the research for ethnobotanical knowledge of other Kewrat community of Angika and Bengali mother tongue of Nepal will be very important for valuable information in this field.

This study can be compared with the various available literatures from Nepal, India and Pakistan. Such as Luitel et al. (2014) documented a total of 161 plant species belonging to 86 families and 144 genera to cure 89 human ailments used by the Tamang community in the Makawanpur district of central Nepal. Pradhan et al. (2020) documented a total of 139 plant species belonging to 74 families were found to have ethnobotanical significance among which herbs accounted for $41 \%$ followed by trees $(29 \%)$, shrubs $(14 \%)$, climbers $(9 \%)$, grasses $(3 \%)$, epiphytes $(1 \%)$, ferns $(1 \%)$, fungi $(1 \%)$, and lichens (1\%) from Khandadevi and Gokulganga Rural Municipality of Ramechhap District of Nepal. Rajbanshi and Thapa (2020) reported 40 species medicinal plants belonging to 32 families traditionally used by Kisan community of eastern Nepal for the treatment of 34 kinds of diseases. Bhatt, and. Kunwar.(2020) recorded 74 species of flowering plants at Bhimdatt-18, (Katan) Kanchanpur district of Far-Western Nepal. Similarly, Kumar et al. (2008) documented 20 important plant species used against various hair disorders, viz.: hair fall, dandruff and graying of hair etc. and as hair tonic by Tharu tribe from 46 villages of Devipatan division of U.P. India. Sher et al. (2020) found 53 medicinal plants of 38 genera, belonging to 25 families from Hindubag Mountain, Lalku valley, District Swat, Pakistan.

\section{Conclusions}

This study has documented the information of ethnobotanical knowledge among the people of Kewrat community and plant diversity of the study area. Out of 60 documented plant species during the study, Acorus calamus L., Azadirachta indica and Aloe vera (L.) Burm.f. were found to be the most popularly used in medicinal as well as cultural aspects. Their in-depth knowledge of application of medicinal plants should be preserved and promoted for the welfare of human kind. This study will also provide the baseline data for the further research in this field.

\section{Declarations}

List of abbreviations: Not applicable.

Ethics approval and consent to participate: The study was conducted by the permission oflocal nongovernmental organization 'Surjapuri Language Development Academy', Sunbarshi municipality ward number 4, Morang district, Nepal.

Consent for publication: Not applicable.

Availability of data and materials: The data was not deposited in public repositories.

Competing interests: The authors do not have any competing interests.

Funding: There was no funding received from any institution.

Authors' contributions: Bishnu Dev Das, Niroj Paudel, Madan Kumar Khadka, Megharaj Paudel, Sajita Dhakal and Amrit KC did the preliminary work, semi-structured interviews, plant collection, data generation, drafted the manuscript, verification and revision of the manuscript reviewed and approved the final version of the manuscript. All authors have equal contribution.

\section{Acknowledgements}

We are thankful to nongovernmental organization 'Surjapuri Language Development Academy', Sunbarshi municipality ward number 4, Morang district, Nepal for the permission to conduct this research and cooperation during the study. We express our gratitude to all the respondents for their humble response and cooperation for providing valuable information during the study.

\section{Literature cited}

Albuquerque UP. 2005. Introdução à etnobotânica. Rio de Janeiro: Interciência.

Austin DF. 2004. Florida Ethnobotany. CRC Press, Boca Raton, US.

Bhatt MD, Kunwar RM. 2020. Distribution pattern and ethnomedicinal uses of plants in Kanchanpur district, Far-Western Nepal, Ethnobotany Research and Applications 20:14, http://dx.doi.org/10.32859/era.20.14.1-21

Bhattarai KR. 2018. Ethnobotanical study of plants used by Thami community in llam District, eastern Nepal, Our Nature 16(1): 55-67. DOI: http://dx.doi.org/ 10.3126/on.v16i1.22123

CBS. 2011. Population Census 2011: National report by the National Planning Commission Secretariat, Central Bureau of Statistics (CBS). Kathmandu, Nepal.

Cotton CM. 1996. Ethnobotany: Principles and Applications. John Wiley and Sons, New York. 
Harshberger JW. 1896. Purpose of ethnobotany. Botanical Gazette 21:146-154.

Jain SK, Rao RR .1967. A handbook of field and Herbarium methods. Today and Tomorrow Printers and Publishers, New Delhi.

Kumar, A., Mishra, A., Pandey, S. and D Tewari, D. 2008 Phytotherapy against Hair Disorder by Tharu tribe in Devipatan Division, U.P., India, Vegetos. 21:85-89.

Luitel DL, Maan B Rokaya MB, Timsina B, Münzbergová Z. 2014. Medicinal plants used by the Tamang community in the Makawanpur district of central Nepal, Journal of Ethnobiology and Ethnomedicine 10:5. doi:10.1186/1746-4269-10-5

Madikizela B, Ndhlala AR, Finnie JF, Van Staden J. 2012. Ethnopharmacological study of plants from Pondoland used against diarrhoea. Journal of Ethnopharmacology 141:61-71.

Mahwasane ST, Middleton L, Boaduo N. 2013. An ethnobotanical survey of indigenous knowledge on medicinal plants used by the traditional healers of the Lwamondo area, Limpopo province, South Africa. South African Journal of Botany 88:69-75.

Malla B, Gauchan DP, Chhetri RB. 2015. An ethnobotanical study of medicinal plants used by ethnic people in Parbat district of western Nepal. Journal of Ethnopharmacology 165:103-117.

Manandhar NP. 1993. Herbal remedies of Surkhet district, Nepal. Fitoterapia 64:66-272.

Manandhar NP. 2002. Plants and people of Nepal. Timber press, USA.

Parthiban R, Vijayakumar S, Prabhu S, Yabesh JGEM. 2016. Quantitative traditional knowledge of medicinal plants used to treat livestock diseases from Kudavasal taluk of Thiruvarur district, Tamil Nadu, India. Revista Brasileira de Farmacognosia 26: 09-121.

Paudel N, Adhikari DC, Das BD. 2018b. Some Medicinal Plants Uses in Ethnical Group from Biratnagar, Eastern, Nepal,American Scientific Research Journal for Engineering, Technology, and Sciences (ASRJETS): 233-239.

Paudel N, Paudel LP, Ghimire U, Das BD. 2017. Archichlamydae and Sympetalae Flora of Arghakhanchi District, Western Nepal, International Journal of Life Sciences Research, 5(3):73-81.

Paudel N, Aryal MR, Das BD, Adhikari DC, Rai PD, Shrestha R. 2018a. Some medicinal plant from Kathmandu Valley, Central Nepal. International Journal of Scientific Report 4(4):78-81.

Polunin O, Stainton A. 1984. Flowers of the Himalaya. Oxford University Press.

Pradhan SP, Chaudhary RP, Sigdel S., Pandey, B.P. 2020. Ethnobotanical knowledge of Khandadevi and Gokulganga Rural Municipality of Ramechhap
District of Nepal, Ethnobotany Research and Applications, doi:10.32859/era.20.07.1-32

Press JR, Shrestha KK, Sutton DA. 2000. Annotated checklist of the flowering plants of Nepal. The Natural History Museum, London.

Rai, SK. 2004. Medicinal Plants used by Meche People of Jhapa District, Eastern Nepal, Our Nature, 2:27-32

Rajbanshi and Thapa .2019. Traditional knowledge and practices on utilizing medicinal plants by endangered Kisan ethnic group of eastern Nepal, Ethnobotany Research and Applications 18:23

Sheng-Ji, P. 2001. Ethnobotanical approaches of traditional medicine studies: some experiences from Asia. Pharmaceutical Biology 39: 4-79.

Sher $\mathrm{H}$, Inamuddin, Khan Z, Bussmann RW, Rahman IU. 2020. Medicinal plant diversity of Hindubag mountain, Lalku valley, District Swat. Ethnobotany Research and Applications 20:09. doi:.32859/era.20.09.1-13

Thorsen RS, Pouliot M. 2015. Traditional medicine for the rich and knowledgeable: challenging assumptions about treatment-seeking behaviour in rural and peri-urban Nepal. Health Policy and Planning 31: 314-324.

WHO 2008. World health statistics 2008. Available online:

http://www.who.int/whosis/whostat/EN_WHS08_Full .pdf. Accessed on 20 January, 2019. 